\title{
Pepper anthracnose in the Philippines: knowledge review and molecular detection of Colletotrichum acutatum sensu lato
}

\author{
Mark Angelo Balendres* and Fe Dela Cueva \\ Institute of Plant Breeding, College of Agriculture and Food Science, University of the Philippines Los \\ Baños, Laguna, Philippines 4031 \\ * Corresponding Author: M. A. Balendres (mobalendres@up.edu.ph)
}

\begin{abstract}
This paper reviews the current knowledge of pepper anthracnose in the Philippines. We present research outputs on pepper anthracnose from the last three years. Then, we present evidence of the widespread occurrence of $C$. acutatum sensu lato in the Philippines. Finally, we highlight some research prospects that would contribute towards developing an integrated anthracnose management program.
\end{abstract}

Keywords: Colletotrichum truncatum, Colletotrichum gloeosporioides, chilli anthracnose, polymerase chain reaction assay, disease distribution

\section{Knowledge review of pepper anthracnose in the Philippines}

\section{Pepper in the Philippines}

Pepper (Capsicum sp.) is an important vegetable crop in the family Solanaceae. It is mainly added as a spice or condiment in various dishes. In the Philippines, there is a demand for pepper in both the fresh and processing markets. However, it is a relatively small industry compared to other vegetable crops, e.g., tomato. The Cordillera and Northern Mindanao regions produce the most but, other areas, e.g., in the CALABARZON and Central Luzon, also steadily produce pepper. The price of pepper can reach to as high as Php1,000 per Kg (USD 20), making pepper cultivation attractive to small-scale growers as a source of income. Within three months, depending on the pepper variety, growers can start harvesting the fruits, that could last to several priming's (harvests). Local growers supply fresh pepper fruits. The change in the grower's preference may affect the supply of pepper. Issues brought by biotic and abiotic factors, which can significantly reduce the yield of marketable fruits, usually contribute to this preference. The Department of Agriculture (Philippines) has identified the high incidence of diseases as among the significant production barriers in vegetable production.

\section{Pepper Anthracnose}

Anthracnose is among the most well-known pepper diseases worldwide. It is characterized by fruits having dark, sunken, lesion which grows or coalesce with other lesions. In some cases, fruits in the field with severe infection mummifies. Not only it reduces yield in the field, but anthracnose can also diminish the quality of fruits during the post-harvest operations. While fruits may show a lack of anthracnose symptoms, the disease could develop later. This phenomenon is due to the ability of the pathogen to enter a quiescent or latent stage (Cannon et al. 2012). When storage and post-harvest conditions favor the growth of the pathogen, symptoms may slowly develop. The ability to reduce yield and decrease the number of marketable fruits make anthracnose as one of the most destructive diseases of fruits and vegetables (Freeman et al., 1998). 
Anthracnose is common in tropical regions, particularly in Asia (Than et al. 2008b), where warm, wet, and humid conditions persist. However, many temperate crops can also be infected (Cannon et al., 2012). The disease has been reported in Indonesia (Voorrips et al. 2004), Korea (Park and Kim 1992), Taiwan (Manandhar et al. 1995), Thailand (Than et al. 2008a), and Vietnam (Don et al. 2007). Pepper anthracnose was first scientifically reported in the Philippines by Ocfemia (1924). In 1977, Quimio reported a different species causing pepper anthracnose in the country. Almost two decades later, Opina (1993) investigated several outbreaks of pepper anthracnose in the provinces of Batangas, Quezon, and Laguna. Severe infections were reported, but little was known of the scale of the damage brought by anthracnose.

Anthracnose can cause 50 to $100 \%$ yield loss globally (e.g., Silva et al. 2005; Poonpolgul and Kumphai 2007). That anthracnose results in a reduction in potential harvests, and marketable fruit yield of pepper in the Philippines, was reported recently by Dela Cueva and Balendres (2017). Moderate to severe anthracnose in both the "sinigang" and "labuyo" type of pepper cultivars were observed in surveyed farms planted with pepper in Batangas. A total yield reduction was recorded in one of the small farms. Some farmers abandon fields planted with crops infected with anthracnose before fruits were harvested. Some of the apparently healthy harvested fruits later developed anthracnose and, subsequently, were rejected during marketing. Even in areas were fruits were still setting, about $3 \%$ of the plants were already showing anthracnose lesions.

The problems associated with anthracnose may affect the supply (reduced) of pepper fruits and, with high demand, may subsequently cause a surge in price. For example, in 2015, according to the Agribusiness and Marketing Assistance Service (AMAS), the price of siling labuyo rose to Php 700 per Kg (USD 14) in some Metro Manila markets in December, due to the low level of supply (Padin 2015). Such a price increase may also be indirectly reflected in meals and foods with pepper as a vital vegetable ingredient. From a consumer perspective, this would be an additional household expense. Not to mention the losses also incurred when healthy fruits brought from the supermarket later developed anthracnose after several days in the fridge.

\section{Etiology of Pepper Anthracnose}

The fungus Colletotrichum spp. causes anthracnose. (sexual stage Glomerella). Colletotrichum species are filamentous fungi that grow well in tropical conditions (frequent rain, warm, and humid). However, it can also thrive in subtropical and some temperate regions (Freeman et al. 1998). Splashes of water (overhead irrigation) or rain quickly disperse fungal spores or conidia. Thus, anthracnose can be severe during the wet season. The fungus can infect on leaves, stems, flowers, and more commonly on fruits.

Several Colletotrichum species cause pepper anthracnose (Mongkolporn and Taylor, 2018), and these species belong to several clades or complexes (Cannon et al. 2012). The commonly reported species are found in the C. gloeosporioides sensu lato (the "gloeosporioides group"), and C. acutatum sensu lato (the "acutatum group"). Some other species belong to the $C$. truncatum sensu lato (the "truncatum group"), $C$. boninense sensu lato ("boninense group"), and $C$. dematium sensu lato ("dematium group"). The "acutatum" (Damm et al., 2012) and "gloeosporioides" (Weir et al., 2012) groups/clades contain many species that are now identified as unique species, as supported by multiple gene analyses (Cannon et al. 2012).

Colletotrichum species associated with pepper anthracnose are C. acutatum sensu stricto, C. boninense, C. brevisporum, $C$. capsici (syn. $C$. truncatum sensu stricto), $C$. coccodes, $C$. dematium, $C$. fructicola, $C$. gloeosporioides sensu stricto, C. karstii, C. siamense, and C. truncatum (Park and Kim 1992; Johnston and Jones 1997; Sharma et al. 2005; Than et al. 2008a; Kim et al. 2008; Diao et al. 2012; Sharma and Shenoy 2014; Diao et al. 2015; Han et al. 2016; Saini et al. 2016; Liu et al. 2016; De Silva et al. 2017). Recently, Liu et al. (2016) reported a new species, C. sichuanensis, causing anthracnose of pepper in Sichuan 
Province, China. The most frequently reported species complexes are $C$. acutatum, $C$. truncatum, and $C$. gloeosporioides (Than et al. 2008b; Weir et al. 2012; Damm et al. 2012). Damm et al. (2012) also reclassified two isolates of $C$. acutatum to now new species, $C$. scovillei and $C$. nymphaeae.

Ocfemia (1924), in the Philippines, reported the cause of pepper anthracnose as C. nigrum (Tangonan, 1999). Quimio (1977) also reported C. capsici. Opina (1993) identified the causal pathogens of pepper anthracnose in the Southern Luzon provinces as C. gloeosporioides and C. capsici. Dela Cueva and Balendres (2017) isolated C. gloeosporioides sensu lato (Figure 1a), C. truncatum sensu lato (Figure 1b), and, for the first time, $C$. acutatum sensu lato (Figure 1c) from anthracnose-infected pepper fruits. Interestingly, C. acutatum sensu lato is a common pathogen of pepper in other countries (Than et al. 2008b) but was only detected in the Philippines just recently (Dela Cueva and Balendres 2017). It was not known if $C$. acutatum sensu lato is present in other regions. Most recently, the $C$. acutatum sensu lato Ca5 isolate was later identified as $C$. scovillei based on combined morpho-cultural, pathogenicity, and molecular characterizations (Balendres et al., 2018). That the pathogen was already present in the country but remained undetected or was introduced into the country remains debatable and would be a subject of future investigations.

\section{Identification of Colletotrichum species associated with anthracnose}

Traditionally, Colletotrichum spp. are identified based on spore morphology, cultural growth, and host range. Species complex can be distinguished by growth in culture media (e.g., potato dextrose agar) and the appearance of the spores (and other morphological features). Some species can also infect a specific host crop. Nevertheless, these features were found inadequate when identifying the species due to morphological similarities of the pathogens under specific conditions or overlapping host range (Wharton and Dieguez-Uribeondo 2004). A polyphasic approach (Cai et al. 2009) has been proposed when identifying species within a species complex. The approach combines morpho-cultural and pathogenicity characteristics with molecular data (Cannon et al., 2012). These molecular data are the DNA sequences of (target) gene regions of the fungus. Mills et al. (1992) and Sreenivasaprasad et al. (1996) were the first to use DNA sequence data, using the internal transcribed spacer (ITS) gene region, in distinguishing Colletotrichum species. Since then, several works have used additional gene regions, e.g., the glyceraldehyde-3-phosphate dehydrogenase (GAPDH), the B-tubulin (BTUB), and the actin (ACT) gene regions (see Cannon et al. 2012). The ITS, GAPDH, and BTUB gene regions have been successfully used in discriminating Colletotrichum species within the "acutatum" (Damm et al. 2012) and "gloeosporioides" group (Weir et al. 2012).

The knowledge of the causal agent of anthracnose is essential when developing and implementing successful disease management. Each species could differ in sensitivity and response to various chemicals (Peres et al., 2004; Peres et al., 2005). Species also differ in pathogenicity to pepper genotypes/cultivar. These were the case of the representative isolates collected from the Philippines (de Castro et al. 2018; Mendoza et al. 2018). Thus, accurate identification of Colletotrichum species causing anthracnose in the field contributes to the success of the chemical application and cultivar deployment.

\section{Current anthracnose management strategies}

There is no single practical disease control approach available for pepper anthracnose. The combination of two or more control strategies has been recommended (Than et al. 2008b). Seeds can be sources of inoculum, and hence, planting certified seeds is highly recommended. Soil health is also as important as planting healthy seeds. Fields planted previously with pepper, which has been infected severely by anthracnose, may be left idle at least for a year. Rotating with non-Solanaceous and non-host crops is advisable in fields with a long history of anthracnose. Weeds can also serve as a reservoir or source of inoculum for the next cropping season. One particular weed is Lantana camara (De Castro AM, Dela Cueva 
FM, and Balendres MA, unpublished observation). Hence, the removal of weeds that could serve as alternative hosts of the fungi could also potentially help in reducing the inoculum pressure.

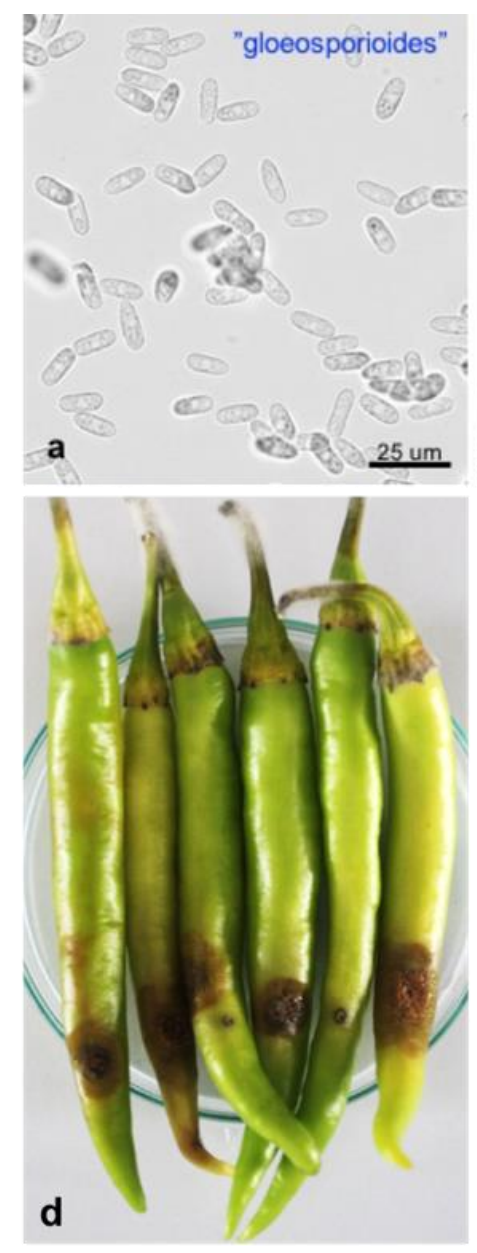

Figure 1. Spore morphology gloeosporioides sensu lato $(\mathrm{a}, \mathrm{d})$,
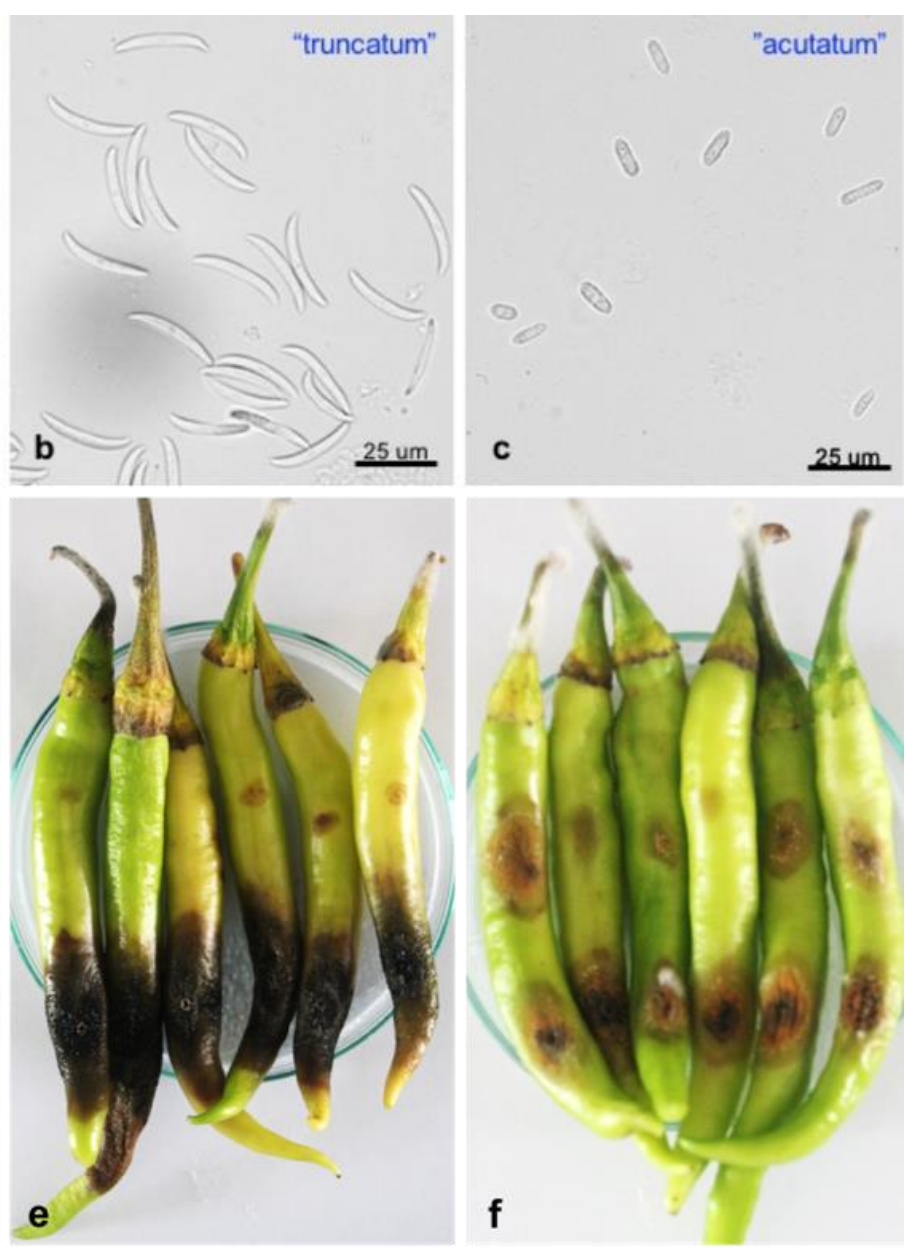
e

Chemicals have been used in anthracnose management. For pepper anthracnose, in other countries, although it does not consistently control, Manganese ethylenebisdithiocarbanae (Maneb) has been recommended (Smith 2000). In the Philippines, several chemicals have been approved for use in pepper anthracnose (by the Fertilizer and Pesticide Authority). Some other chemicals have also shown promising results in vitro trials (Balendres et al. 2018). Nevertheless, the use of some fungicides has been discouraged due to the potential adverse effects of the chemicals on human health and the environment (Voorrips et al. 2004; Than et al. 2008b). One alternative to fungicides (pesticides) are bio-fungicides. A bio fungicide that contains Bacillus subtilis, a popularly known biological control agent, has shown some promising results. In vitro pathogen growth was completely inhibited, and lesion development in fruits was delayed or reduced as compared to fruits that were not treated with any chemicals (Dela Cueva and Balendres 2018; Balendres et al. 2018). Citronella (Cymbopogon spp.) essential oil (CEO) has also been shown to completely inhibit C. acutatum sensu lato growth in PDA amended with CEO. CEO also delayed the development of anthracnose in fruits. The effect of the CEO on disease development was comparable to that of the bio fungicide and other chemical treatments (Dela Cueva and Balendres 2018). 
Perhaps the cheapest, safest, and most sustainable approach to anthracnose management is the use of resistant cultivar or genotype. However, little is known of pepper genotypes in the country with resistance to anthracnose. Pepper cultivars have some degree of susceptibility to anthracnose. Than et al. (2008b) outlined some works done elsewhere that investigated some promising dominant gene responsible for resistance to pepper anthracnose. Opina (1993), in the Philippines, found three pepper lines with resistance to anthracnose under natural field conditions, and these lines could serve as sources of resistance for further breeding work. Most recently, Mendoza et al. (2018) also found, in a preliminary screening, some promising pepper accessions from the National Plant Genetic Resources Laboratory (NPGRL) at IPB, UPLB. Anthracnose did not develop in these relatively resistant pepper accessions in both wounded and unwounded detached fruit assay.

\section{Molecular detection of C. acutatum sensu lato in the Philippines}

Colletotrichum species cause anthracnose of a wide range of plant species, including fruits and vegetables. In the Philippines, there are 57 reported hosts of 21 reported Colletotrichum species (Tangonan and Quebral, 1992; Balendres 2019). The identity of these species was based mainly on morphological and cultural characteristics of the isolated fungi and based on the host species (for example, C. melongena was isolated from Solanum melongena). However, the list includes several unrecognized species. For example, C. coffeanum, C. melongena, C. euchroum, C. ficus, C. papayae are not recognized in the current Colletotrichum systematics (Cannon et al. 2012). Because no specimens were kept, reidentification would be very challenging.

Anthracnose is one of the most destructive plant diseases globally. It can significantly reduce yield up to $100 \%$ (Dela Cueva and Balendres 2017) and can negatively affect the marketability of the produce. In 2017, Dela Cueva and Balendres reported an occurrence of anthracnose in pepper that is caused by $C$. acutatum sensu lato, which was a first report in the country. Noteworthy, this pathogen is common in other Southeast Asian countries, yet rarely and only reported that time in the country. The C. acutatum sensu lato was isolated from an anthracnose-infected pepper fruit from Batangas, Philippines. The presence of $C$. acutatum sensu lato in other provinces in the Philippines is yet to be determined.

This section aims at detecting C. acutatum sensu lato in anthracnose-infected pepper from the Visayas, Mindanao, and some provinces in Luzon, Philippines, using a rapid DNA extraction-PCR tandem method (Balendres and Dela Cueva 2018). Anthracnose-infected pepper fruits were collected from select areas in Luzon (Ilocos, Tarlac, Cavite, Batangas, Laguna, Quezon, and Bicol), Visayas (Cebu and Bacolod), and Mindanao (Bukidnon and Cagayan de Oro) between 2017-2018. All pepper fruit samples from Visayas and Mindanao were brought to the Plant Pathology Laboratory, Institute of Plant Breeding, College of Agriculture and Food Science, University of the Philippines Los Baños, under the license of the Bureau of Plant Industry-National Plant Quarantine Services Division (BPI-NPQSD).

The anthracnose-infected tissues were cut into $3 \times 3 \mathrm{~mm}$ block size, and these were surface-sterilized in $10 \%$ sodium hypochlorite solution (v/v, Zonrox). Tissues were washed three times in sterile distilled water, air-dried in sterile tissue paper, and then placed onto potato dextrose agar (PDA) medium. Plates were incubated at $28{ }^{\circ} \mathrm{C}$ for five days. The actively growing hyphae of the fungus were transferred, and single spore isolated, to a new PDA medium for subsequent DNA extraction and PCR analysis (Balendres and Dela Cueva 2018). The pathogenicity assay was performed in pepper cultivar Django fruits following the procedure of Dela Cueva and Balendres (2017). The fungal genomic DNA used as a template in the PCR assay was extracted using the method described by Balendres and Dela Cueva (2018) that was modified from the procedure used by Talbot's Laboratory (University of Exeter, UK). PCR amplification of the target gene regions was performed in a Speedcycler thermal cycler using the conditions optimized by Balendres and Dela Cueva (2018). 
Of the 66 Colletotrichum Philippine isolates, 37, 9, and 20 were C. acutatum sensu lato, C. gloeosporioides sensu lato, and $C$. truncatum sensu lato, respectively (Table 1 ). The $C$. acutatum sensu lato was detected in all three main islands. The results indicate the wide distribution of $C$. acutatum in the Philippines, and it is also the most commonly isolated Colletotrichum species complex. This study is the first report of $C$. acutatum sensu lato in the island of Mindanao and other provinces (except Batangas and Quezon) in Luzon. Identification of C. acutatum sensu lato and their distribution in the country could assist plant breeders in developing durable disease-resistant plants and in providing the relevant agencies the baseline information of $C$. acutatum sensu lato distribution in the country.

Table 1 . The number of isolates collected from the three island groups and their identity.

\begin{tabular}{|c|c|c|c|c|}
\hline $\begin{array}{l}\text { Island } \\
\text { Group }\end{array}$ & Area & $\begin{array}{l}\text { C. gloeosporioides } \\
\text { sensu lato }\end{array}$ & $\begin{array}{l}\text { C. truncatum } \\
\text { sensu lato }\end{array}$ & $\begin{array}{c}\text { C. acutatum } \\
\text { sensu lato }\end{array}$ \\
\hline \multirow[t]{4}{*}{ Luzon } & Batangas & 4 & 0 & 18 \\
\hline & Bicol & 0 & 2 & 9 \\
\hline & Tarlac & 1 & 1 & 6 \\
\hline & Sub-total & 5 & 3 & 33 \\
\hline \multirow[t]{2}{*}{ Visayas } & Bacolod & 3 & 6 & 0 \\
\hline & Sub-total & 3 & 6 & 0 \\
\hline \multirow[t]{5}{*}{ Mindanao } & Bukidnon & 0 & 10 & 2 \\
\hline & Davao & 0 & 0 & 1 \\
\hline & Cagayan de Oro & 1 & 1 & 1 \\
\hline & Sub-total & 1 & 11 & 4 \\
\hline & Total & 9 & 20 & 37 \\
\hline
\end{tabular}

\section{Research Prospects}

Colletotrichum species are known to infect various plant species. Several Colletotrichum species causes anthracnose in fruits and vegetables in the Philippines (Tangonan 1999). However, little is known of the cross-infection potential of the current species to other crops. There is also a dearth of information on host range and the epidemiology of Colletotrichum species currently infecting pepper in the country, particularly C. scovillei. Such knowledge would be useful in developing an effective crop rotation program for anthracnose management. While evidence has been presented that $C$. acutatum sensu lato is a common pepper anthracnose pathogen, additional isolates are still needed particularly during a different growing season.

The search for alternatives to fungicides can be further explored. Plant-derived substances or metabolites can be assayed (Chitwood, 2002; Balendres et al., 2016) for antifungal activity against the anthracnose pathogens. However, one factor to consider is the phytotoxicity of the chemical. Dela Cueva and Balendres (2018) found that the CEO at $2.5 \mathrm{uL} / \mathrm{mL}$ water was toxic to and damaged the pepper fruits. The remedy was to lower the concentration of $\mathrm{CEO}$, at $1.25 \mathrm{ul} \mathrm{CEO} / \mathrm{mL}$ water, at a level that is not toxic to the fruits while still controlling the disease. There are currently no known commercial BCA for anthracnose management in the country. Hence, aside from safe chemical alternatives, biological control agents (BCA) are to be considered. Identifying active compounds from these potential BCAs would also be worthwhile. Glasshouse and field trials would be needed to establish further the effectiveness of certain bio fungicides and botanical extracts as alternatives to fungicides (pesticides) in pepper anthracnose management. 
Cultivar resistance is the most sustainable and relatively, the cheapest approach to combat anthracnose. However, no pepper cultivar currently grown in the field is resistant to anthracnose. If there is, there may be some variable response of these cultivars to different Colletotrichum species. Germplasm collections could be used for disease screening studies. There are currently more than 1,000 pepper accessions at the NPGRL-IPB-UPLB, and some other accessions may be sourced elsewhere. Pepper breeding lines and other pepper genotypes produced during pre-breeding activities can also be tapped in for anthracnose resistance screening. These accessions and breeding lines are also potential sources of resistance to anthracnose that can be used in subsequent pepper breeding program and resistant-gene marker mining.

\section{Conclusion}

Anthracnose is a destructive disease of pepper that reduces yield and results in monetary losses. The last three years have provided new insights into the Colletotrichum-pepper pathosystem in the country. Currently, C. gloeosporioides sensu lato, C. truncatum sensu lato, C. acutatum sensu lato, and C. scovillei are associated with pepper anthracnose. Polyphasic identification has made detection and identification more rapid and robust. While no single disease control approach is in place, research towards the development and identification of potential disease mitigating approaches is steadily gaining momentum. Bio fungicides are being assessed, and promising results have been observed. Potential sources of resistance to anthracnose in pepper germplasm are now being selected. Nevertheless, until farmers are provided with useful tools, methods, and cultivars that would contribute to controlling pepper anthracnose, the research is far from complete. Cultural methods that include mulching, removal of weeds, and immediately eradicating infected plant parts, with proactive disease monitoring, remains vital in mitigating disease impact.

\section{Acknowledgments}

Research on pepper anthracnose was supported by the Institute of Plant Breeding, College of Agriculture and Food Science, University of the Philippines Los Baños. We thank JayVee Mendoza, Rachele De Torres, Niño Laurel, Alyssa de Castro, Fatima Silva, Catherine Hazel Aguilar, Rizalina Tiongco, Meldy Vibal, Amalia Ilagan, Vangeline Linga, Eddie Bueta, Dante Tiongco, Cherry Relevante, Jamie Tumolva, Cecilia Pascual, Alben Manilay, Jose Alcantara, Edwin Aquino, Jerymiah Cortejo, Rodelio Pia, Jennelyn Bengoa, Maria Cielo Paola Rodriguez, Julie Bituin, Rodel Maghirang, and Villamor Ladia, for technical assistance. We also thank Irish Posada, Cyrose Suzie Millado, Iris Pescadero, Keven Mark Jimenez, Hans Christian Mahilum, Alvin Edades, and Bernard Panabang for providing some anthracnose-infected pepper fruits. Likewise, we thank the Provincial and Municipal Agriculture Officers of Cavite, Misamis Oriental and Northern Mindanao and the chilli growers of Laguna, Batangas, Quezon, and Cavite for the assistance during sample collection.

\section{Conflict of Interest}

The authors declare that they have no conflict of interests.

\section{Ethical Approval}

This article does not contain any studies with human participants or animals performed by any of the authors. Hence, approval from the ethics board was not required.

\section{References}

Balendres MA, Dela Cueva FM. Rapid detection of Colletotrichum spp. using a modified DNA extractionSpeedCycler ${ }^{\mathrm{TM}}$ tandem method. J Trop Plant Pathol; Pathology, 54, 58-69. 
Balendres MA, Mendoza JS, Tiongco R, Aguilar CH, Rodriguez MC, Maghirang R, Dela Cueva FM. The current state of pepper anthracnose in the Philippines. In 1st State of the World's Fungi Symposium, September 13-14, 2018, Kew Gardens, Richmond, United Kingdom.

Balendres MA, Nichols DS, Tegg RS, Wilson CR. Metabolomes of potato root exudates: compounds that stimulate resting spore germination of the soil-borne pathogen Spongospora subterranea. J Agric Food Chem 2016; 64: 7466-7474.

Cai L, Hyde KD, Taylor PWJ, et al. A polyphasic approach for studying Colletotrichum. Fungal Divers 2009; 39: 183-204.

Cannon PF, Damm U, Johnston PR, Weir BS. Colletotrichum - current status and future directions. Stud Mycology 2012; 73; 181-213.

Chitwood D. Phytochemical based strategies for nematode control. Ann Rev Phytopathol 2002; 40; 221249.

Damm U, Cannon PF, Woudenberg JHC, Crous PW. The Colletotrichum acutatum species complex. Stud Mycology 2012; 73: 37-113.

De Castro AM, Balendres MA, Tiongco R, Dela Cueva FM. Growth and sporulation of three Colletotrichum species as influenced by organic chemicals. 40th Annual Scientific Meeting of the National Academy of Science and Technology, Philippines, July 11-12, 2018, The Manila Hotel.

De Silva DD, Ades PK, Crous PW, Taylor PWJ. Colletotrichum species associated with chili anthracnose in Australia. Plant Pathol 2017; 66 (2):254-267.

Dela Cueva FM, Balendres MA. Elucidating the cause and impact of a chilli anthracnose outbreak in Batangas, Philippines. J Trop Plant Pathol 2017; 53: 37-51.

Dela Cueva FM, Balendres MA. Efficacy of citronella essential oil for the management of chilli anthracnose. Eur J Plant Pathol 2018; 152 (2): 461-468.

Dela Cueva FM, Mendoza JS, Balendres MA, 2018. A new Colletotrichum species causing anthracnose in chilli in the Philippines and its pathogenicity to chilli cv. Django. Crop Prot 2018; 112: 264-268.

Diao Y, Zhang C, Xu J, et al.. Genetic differentiation and recombination among geographic populations of the fungal pathogen Colletotrichum truncatum from chili peppers in China. Evol Applic 2015; 8: 108-118.

Diao YZ, Fan JR, Wang ZW, Liu XL. First report of Colletotrichum boninense causing anthracnose on pepper in China. Plant Dis 2012; 97: 138.

Don LD, Van TT, Phuong Vy TT, Kieu PTM. Colletotrichum spp. attacking on chilli pepper growing in vietnam. Country report. In: Oh DG, Kim, K.T., ed. Proceedings of the Abstracts of the First International Symposium on Chilli Anthracnose, 2007: National Horticultural Research Institute, Rural Development of Administration, Republic of Korea.

Freeman S, Katan T, Shabi E. Characterization of Colletotrichum species responsible for anthracnose diseases of various fruits. Plant Dis 1998; 82: 596-605. 
Han JH, Chon JK, Ahn JH, Choi IY, Lee YH, Kim KS. Whole genome sequence and genome annotation of Colletotrichum acutatum, causal agent of anthracnose in pepper plants in South Korea. Genomics Data 2016; 8: 45-46.

Johnston PR, Jones D. Relationships among Colletotrichum isolates from fruit-rots assessed using rDNA sequences. Mycologia 1997; 89: 420-430.

Kim JT, Park SY, Choi WL, Y.H., Kim HT. Characterization of Colletotrichum isolates causing anthracnose of pepper in Korea. Plant Pathol J 2008; 24: 17-23.

Liu F, Tang G, Zheng X, et al.. Molecular and phenotypic characterization of Colletotrichum species associated with anthracnose disease in peppers from Sichuan Province, China. Scientific Reports 2016; 6: 32761.

Manandhar JB, Hartman GL, Wang TC. Anthracnose development on pepper fruits inoculated with Colletotrichum gloeosporioides. Plant Dis 1995; 79: 380-383.

Mendoza JS, Dela Cueva FM, Balendres MA. Sources of resistance to chilli anthracnose in the Philippines. In 50th PMCP Anniversary and Annual Scientific Conference, May 8-11, 2018. The Mansion, Iloilo City, Philippines.

Mills PR, Sreenivasaprasad S, Brown AE. Detection and differentiation of Colletotrichum gloeosporioides isolates using PCR. FEMS Microbiol Lett 1992; 98: 137-143.

Mongkolporn O, Taylor PWJ. Chili anthracnose: Colletotrichum taxonomy and pathogenicity. Plant Pathol 2018; 67 (6): 1255-1263.

Ocfemia GO. Notes on some economic plant diseases new in the Philippine islands. Philipp Agr 1926; 13: 163-165.

Opina NL. Occurrence, seed transmission and identification of Colletotrichum species causing pepper anthracnose in the Philippines and varietal screening for resistance. Philipp Phytopathol 1993; 29: 72-83.

Padin MG. Price of 'siling labuyo up to P700 a kilo. Business Mirror, December 7, 2015.

Park KS, Kim CH. Identification, distribution and etiological characteristics of anthracnose fungi of red pepper in Korea. Kor J Plant Pathol 1992; 3: 85-92.

Peres NaR, De Souza NL, Peever TL, Timmer LW. Benomyl sensitivity of isolates of Colletotrichum acutatum and C. gloeosporioides from citrus. Plant Disease 2004; 88: 125-130.

Peres NaR, Timmer LW, Adaskaveg JE, Correll JC. Lifestyles of Colletotrichum acutatum. Plant Dis 2005; 89: 784-96.

Poonpolgul S, Kumphai S. Chilli pepper anthracnose in Thailand. In: Oh DG, Kim, K.T., ed. Proceedings of the Abstracts of the First International Symposium on Chilli Anthracnose, 2007: National Horticultural Research Institute, Rural Development of Administration, Republic of Korea.

Quimio TH. Species of Colletotrichum in the Philippines. Nova Hedwigia 1977; 28. 
Saini T, Gupta S, Char B, Zehr U, Anandalakshmi R. First report of chilli anthracnose caused by Colletotrichum karstii in India. New Dis Rep 2016; 34.

Sharma G, Shenoy BD. Colletotrichum fructicola and $C$. siamense are involved in chilli anthracnose in India. Arch Phytopathol Plant Prot 2014; 47: 1179-1194.

Sharma PN, Kaur M, Sharma OP, Sharma P, Pathania A. Morphological, pathological and molecular variability in Colletotrichum capsici, the cause of fruit rot of chillies in the subtropical region of North-Western India. J Phytopathol 2005; 153: 232-237.

Silva LP, Ueno B, Moura AB. Antracnose causa severas perdas na produção de pimenta vermelha no Sul do Rio Grande do Sul. Fitopatologia Brasileira 2005; 30.

Smith KL. Peppers. In: Precheur, R.J. (Ed.), Ohio Vegetable Production Guide. Ohio State University Extension, Columbus, Ohio. 2000; 166-173.

Sreenivasaprasad S, Sharada K, Brown AE, Mills PR. PCR-based detection of Colletotrichum acutatum on strawberry. Plant Pathol 1996; 45: 650-655.

Tangonan N. Host index of plant diseases in the Philippines. Nueva Ecija, Philippines: Department of Agriculture, Philippine Rice Research Institute, 1999.

Than PP, Jeewon R, Hyde KD, Pongsupasamit S, Mongkolporn O, Taylor PWJ. Characterization and pathogenicity of Colletotrichum species associated with anthracnose on chilli (Capsicum spp.) in Thailand. Plant Pathol 2008a; 57: 562-572.

Than PP, Prihastuti H, Phoulivong S, Taylor PWJ, Hyde KD. Chilli anthracnose disease caused by Colletotrichum species. J Zhejiang Uni SCIENCE B 2008b; 9: 764-778.

Voorrips RE, Finkers R, Sanjaya L, Groenwold R. QTL mapping of anthracnose (Colletotrichum spp.) resistance in a cross between Capsicum annuum and C. chinense. Theor Appl Gen 2004; 109: 12751282.

Weir BS, Johnston PR, Damm U. The Colletotrichum gloeosporioides species complex. Stud Mycology 2012; 73: 115-180.

Wharton PS, Dieguez-Uribeondo J. The biology of Colletotrichum acutatum. Anales del Jardin Botanico de Madrid 2004; 61: 3-22. 